\title{
Tourniquet-associated povidone-iodine-induced chemical burns
}

\author{
Prasad Ellanti, Conor Hurson
}

Department of Orthopaedic Surgery, Cappagh National Orthopaedic Hospital, Dublin, Ireland

\section{Correspondence to} Dr Prasad Ellanti, prasad.ellanti@gmail.com

Accepted 9 February 2015
To cite: Ellanti $P$, Hurson C. BMJ Case Rep Published online: [please include Day Month Year] doi:10.1136/ bcr-2014-208967

\section{DESCRIPTION}

A 75-year-old man underwent routine left total knee arthroplasty under a spinal anaesthetic. An adequately sized pneumatic tourniquet with wool padding was used and a clear adhesive drape applied circumferentially around the thigh to isolate the tourniquet. A $10 \% \mathrm{w} / \mathrm{w}$ povidone-iodine solution had been used to prepare the left leg. The tourniquet was inflated just prior to cementation of the implants with a tourniquet time of $40 \mathrm{~min}$. The total operative time was $95 \mathrm{~min}$. The patient began to report thigh pain the following day. Examination of the thigh revealed erythema similar to the pattern of povidone-iodine staining with areas of blistering (figures 1 and 2) over the anterior and lateral thigh. Pain symptoms had resolved by day 4 postoperatively and the blisters had fully resolved by the 6 -week outpatient review.

Tourniquet-associated complications include postoperative pain and swelling, injury to skin, nerves and vessels, necrosis of digits and compartment syndrome. ${ }^{1}$ Chemical burns as a result of impregnation of the tourniquet padding with the chemical agents used for skin preparation have been previously reported and are rare. ${ }^{2}{ }^{3}$ They can cause blistering, as in our case, which resolves within a few weeks, or progress to full-thickness injuries that can take several months to heal. ${ }^{3} \mathrm{~A}$ waterproof barrier is recommended to isolate the tourniquet to prevent such injuries. ${ }^{3}$ The adhesive drape used routinely to prevent such burns had likely peeled away in places during the preparation

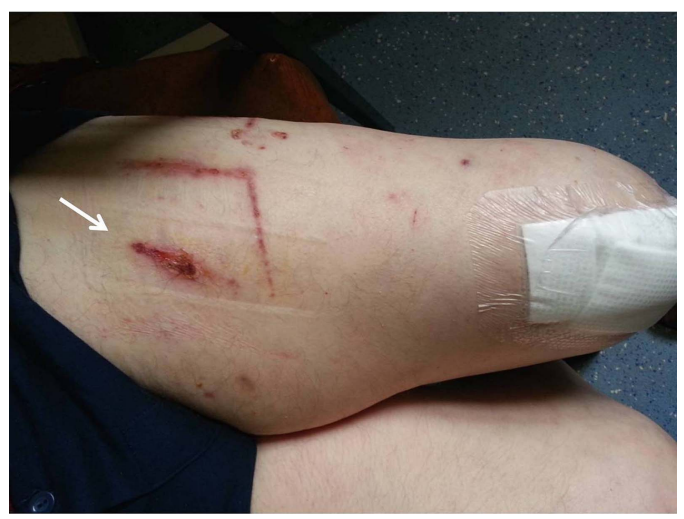

Figure 1 Clinical photograph of the anterior thigh demonstrating a large blister (white arrow).

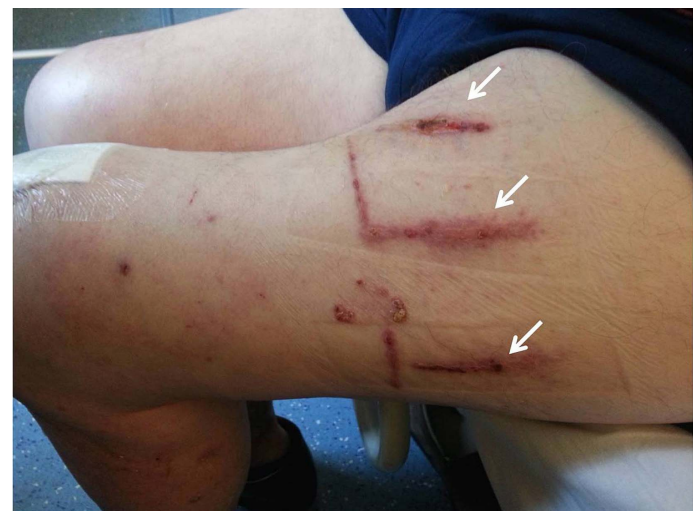

Figure 2 Clinical photograph of the lateral thigh demonstrating multiple blisters (white arrows) and linear areas of erythema.

of the limb for surgery allowing for the pooling and impregnation of the cast padding.

\section{Learning points}

Chemical burns associated with tourniquet use are rare and preventable.

- A waterproof barrier is recommended to isolate the tourniquet to prevent pooling and impregnation of the padding.

- Routine inspection of the tourniquet after surgery is advocated, especially after a spinal anaesthetic, where sensation may be absent for several hours after the surgery.

Competing interests None.

Patient consent Obtained.

Provenance and peer review Not commissioned; externally peer reviewed.

\section{REFERENCES}

1 Sharma JP, Salhotra R. Tourniquets in orthopedic surgery. Indian J Orthop 2012;46:377-83.

2 Dickinson JC, Bailey BN. Chemical burns beneath tourniquets. BMJ 1988;297:1513.

3 Yang JH, Lim H, Yoon JR, et al. Tourniquet associated chemical burn. Indian J Orthop 2012;46:356-9. 


\section{Images in...}

Copyright 2015 BMJ Publishing Group. All rights reserved. For permission to reuse any of this content visit http://group.bmj.com/group/rights-licensing/permissions.

BMJ Case Report Fellows may re-use this article for personal use and teaching without any further permission.

Become a Fellow of BMJ Case Reports today and you can:

- Submit as many cases as you like

- Enjoy fast sympathetic peer review and rapid publication of accepted articles

- Access all the published articles

- Re-use any of the published material for personal use and teaching without further permission

For information on Institutional Fellowships contact consortiasales@bmjgroup.com

Visit casereports.bmj.com for more articles like this and to become a Fellow 